\title{
Sensitivity to Halothane and its Relationship to the Development of PSE (Pale, Soft, Exudative) Meat in Female Lineage Broilers
}

\author{
Denis Fabrício Marchi ${ }^{1}$, Marco Antônio Trindade ${ }^{2}$, Alexandre Oba ${ }^{1}$, Adriana Lourenço \\ Soares $^{1}$, Elza Iouko Ida ${ }^{1}$, José Bento Sterman Ferraz ${ }^{2}$, Tércio Michelan Filho ${ }^{3}$, Iris \\ Lamberti Ziober $^{1}$ and Massami Shimokomaki ${ }^{1 *}$ \\ ${ }^{1}$ Departamento de Ciência e Tecnologia de Alimentos; Universidade Estadual de Londrina; 86051-970; Londrina- \\ $P R$ - Brasil. ${ }^{2}$ Faculdade de Zootecnia e Engenharia de Alimentos; Universidade de São Paulo; 13635-900; \\ Pirassununga - SP - Brasil. ${ }^{3}$ Aviagen do Brasil Ltda - Brasil
}

\begin{abstract}
This work aimed to evaluate female lineage broilers for halothane sensitivity and for their susceptibility to the subsequent development of PSE meat. The halothane test was carried out in an anesthetic chamber with $3.0 \%$ halothane. The unconscious birds were examined for leg muscle rigidity. If one or both legs became extended and rigid, the birds were classified as halothane sensitive (HAL+), while unresponsive birds were classified as halothane negative (HAL-). The results showed that of 298 birds aged 42 days old, 95.6\% were HAL-and $4.4 \%$ were HAL+. A sample of pectoralis major muscle was collected from HAL- $(n=105)$ and HAL+ $(n=13)$ birds. The $\mathrm{pH}$ and breast fillet color were determined at $4^{\circ} \mathrm{C}, 24$ hours post-mortem. Interestingly, only $2.5 \%$ of HAL+ birds displayed PSE meat characteristics compared to $12.7 \%$ of HAL-individuals. The halothane test demonstrated that female lineage broilers displayed very little sensitivity towards halothane, indicating that the development of PSE meat is related to other environmental factors.
\end{abstract}

Key words: Environmental factors, Pectoralis major, Meat color abnormality

\section{INTRODUCTION}

The modern broiler is a result of genetic selection driven by the economic need to produce birds with greater muscle mass and a quicker growth rate (Oba et al., 2006). Both male and female birds are used to produce broiler meat, while for laying eggs, only female birds from female line are used (Santini, 2004). However, so far, little consideration has been given to examining the impact that this genetic selection for rapid growth and muscle mass gain can have on the muscle development. In some cases, it has been shown to cause abnormalities such as myopathy, which results from increased muscle fiber development in the transversal area (Scheuermann, 2005). Among these muscle abnormalities, the development of PSE (pale, soft, exudivate) meat is probably the main factor being currently evaluated. PSE meat occurs due to post mortem rapid glycolysis associated with a quick $\mathrm{pH}$ drop while the carcass is still hot (Bendal and Wismer-

\footnotetext{
* Author for correspondence: mshimo@uel.br
} 
Perdersen, 1962). This association between $\mathrm{pH}$ and high temperature causes meat protein denaturation, impairing the functional properties of the protein and giving rise to meat surface exudates (Candek-Potokar et al., 1998, Olivo et al, 2001).

In pigs, PSE meat is the end result of Pork Stress Syndrome (PSS) symptoms. There is a relationship between PSS and animal susceptibility to halothane anesthetic; particularly in those individuals that are ryanodine mutation carriers, as observed through leg rigidity (Mickelson and Louis, 1996). Leg rigidity results from an increase in anaerobic metabolism and corresponding excessive muscle contraction (Mitchell and Heffron, 1982). This genetic relationship has been demonstrated by Fujii et al. (1991), who reported the existence of a point mutation in the ryr 1 gene that is responsible for coding ryanodine. This protein controls $\mathrm{Ca}^{2+}$ in excitation-contraction coupling within the sarcoplasmic reticulum and is responsible for accelerated muscle metabolism, which causes PSE meat formation in pigs (Mickelson and Louis, 1996). The hal gene is related to an animal's halothane sensitivity. The dominant form of this gene in pigs produces a normal phenotype (NN); sensitive animals are recessive ( $\mathrm{nn})$ and the hybrids are intermediate
(Nn) (Fujii et al., 1991). Bird sensitivity towards halothane has already been studied by several authors (Wheller et al., 1999; Owens et al., 2000; Cavitt et al., 2004, Olivo et al., 2001, Guarnieri et, 2004, Soares et al., 2007), however, few reports have focused on the occurrence of halothane sensitivity in female lineage broilers. The objective of this work was to evaluate female lineage broilers for their sensitivity to halothane gas and the possible relationship to the development of PSE meat.

\section{MATERIALS AND METHODS}

\section{Animals}

Female lineage broilers aged 42 days $(n=298)$ and grown by a broiler chicken company in Minas Gerais, Brazil, were taken to the Pirassununga Campus at São Paulo University.

\section{Halothane test}

The halothane test was carried out in a specially designed chamber similar to the one described in Marchi et al. (2009). This chamber is composed of three compartments where each bird is inserted, as seen in Figure 1.

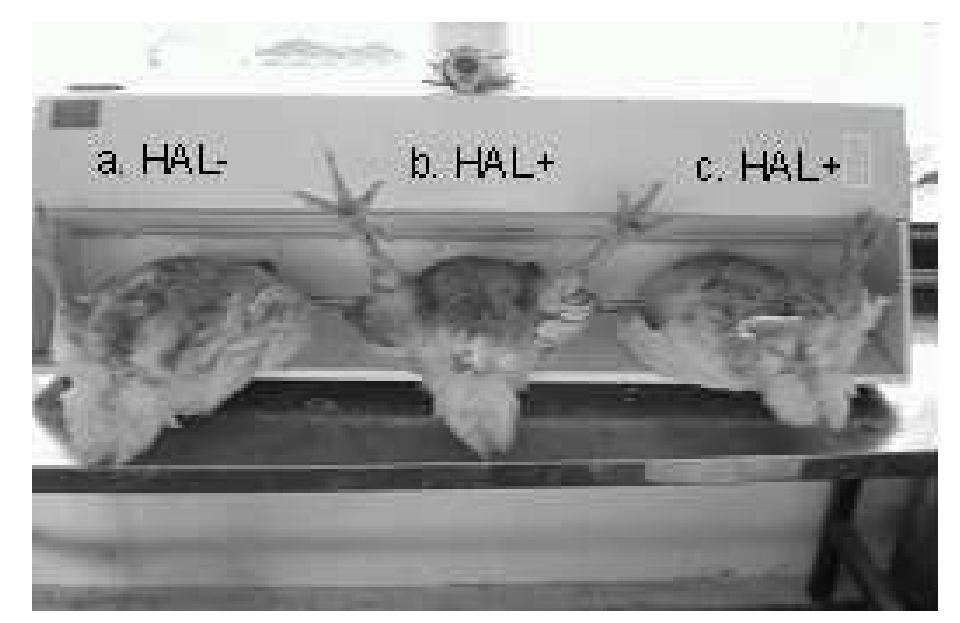

Figure 1 - Broiler leg rigidity as a response to sensitivity to $3.0 \%$ halothane gas: a) non-responder, HAL-, b) and c) responder, HAL+.

Anesthesia was administered for 5 minutes, after which the birds were examined for muscle rigidity in their legs while they were unconscious. If the muscles in at least one leg were stiff, the birds were classified as halothane sensitive (HAL+). If no response was observed, broiler chickens were classified as halothane negative (HAL-). 
Observations of leg rigidity were made by three alternating judges and one fixed judge (Wheller et al., 1999; Owens et al., 2000). In this manner, birds were classified into two groups: HAL+, rigid legs as a response to halothane and HAL-, no response to halothane. These can be seen in the Figure 1.

\section{Slaughter}

Approximately 3-4 hours after the halothane test was administered the broilers were slaughtered mimicking routine commercial line procedures as closely as possible. After approximately $30 \mathrm{~min}$ the pectoralis major muscle was collected from 13 $\mathrm{HAL}+$ and $105 \mathrm{HAL}$ - individuals. The initial $\mathrm{pH}$ value $\left(\mathrm{pH}_{\mathrm{i}}\right)$ was measured for each sample. Breast fillets were kept at $4^{\circ} \mathrm{C}$ for 24 hours post mortem (Guarnieri et al., 2004). After this storage period a second $\mathrm{pH}$ test $\left(\mathrm{pH}_{\mathrm{f}}\right)$ was performed. A color test $\left(L^{*}, a^{*}, b^{*}\right)$ using the CIELAB system was also performed for each sample (Guarnieri et al., 2004).

\section{Determination of PSE meat characteristics}

PSE breast fillet meat was characterized using $\mathrm{pH}$ $(<5,9)$ and color $\left(\mathrm{L}^{*} \geq 53,0\right)$. Color was assessed using the $\mathrm{L}^{*}$ values described in Olivo et al. (2001). The $\mathrm{pH}$ was measured with a Testo $205 \mathrm{pH}$ meter by inserting an electrode into the breast muscle. A Minolta CR 400 colorimeter was used to evaluate the $\mathrm{L}^{*}$ value (CIELAB color system) on the Pectoralis major muscle at the posterior surface of intact skinless fillets 24 hours postmortem.

\section{RESULTS AND DISCUSSION}

\section{Halothane test}

Figure 2 presents the occurrence of HAL+ and HAL- in female lineage broilers. Of the 298 evaluated birds only $4.4 \%$ were halothane responders (HAL+) and $95.6 \%$ were halothane non-responders (HAL-). The lower incidence of HAL+ observed in this study is likely due to all of these samples originating from a female lineage. This lineage has been specifically designed for reproductive improvement, rather than for the production of higher yield muscle mass as is common in male lineage (Scheuermann, 2005).

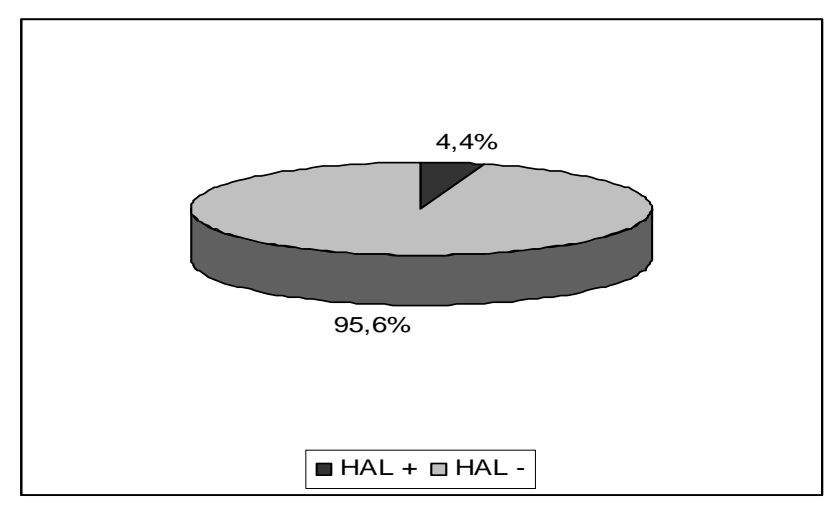

Figure 2 - Incidence of broilers that were halothane responders (HAL+) and halothane nonresponders (HAL-) after submission to $3.0 \%$ halothane gas for 5 minutes.

Lineages that are developed for increased muscle mass are indirectly made more susceptible to the formation of PSE meat (Oba et al., 2006). As previously stated, the main cause of pig PSE meat is related to the ryr 1 gene mutation (Fujii et al., 1991). Our results show that this is probably not the case for broilers in the female lineage, as this lineage exhibits a low incidence of halothane responders (HAL+) as can be seen in Figure 2.

\section{PSE meat occurrence}

From Figure 3, it can be observed that HAL+ birds exhibited only three cases of PSE meat, while in the HAL- group, there were 15 cases of PSE meat in the 105 evaluated samples. Therefore, the HAL+ group contributed with $2.5 \%$ and the HALgroup with $12.7 \%$ of PSE meat from the total evaluated birds. 


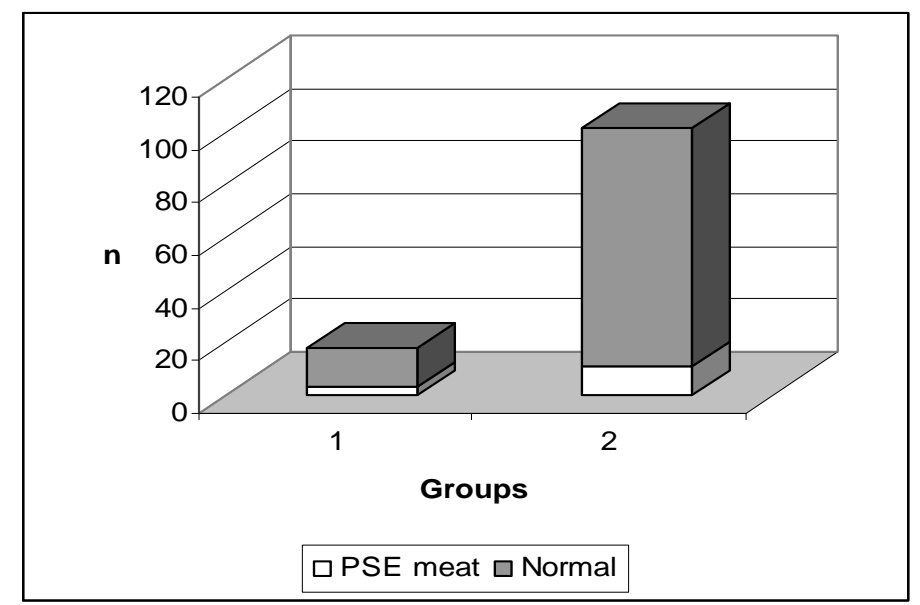

Figure 3 - Incidence of PSE meat in female broiler breast fillets from the two groups: 1) HAL+ and 2) HAL-, after halothane testing, showing the general absence of this abnormality in the female lineage broilers.

Female lineage broilers can, however, produce PSE meat. It is probable that the high occurrence of PSE meat in male lineage broilers is due to their breeding for higher muscle mass gain and quicker growth (Dransfield and Sosnicki, 1999). Scheuermann (2005) reported that the genetic selection of male lineage broilers for increased muscle development promoted the incidence of anomalies such as myopathy, which occurs when there is an increase in muscle fibers in the transversal area. Increased occurrence of PSE meat was also observed in these animals. In the results presented here, it is demonstrated that the incidence of PSE meat in broilers from female lineages is caused by environmental and phenotypic factors, rather than the hal gene mutation as reported for a commercial male broiler lineage (Soares et al., 2002; Guarnieri et al., 2004, Simões et al., 2009).

\section{CONCLUSION}

The halothane test demonstrated that broilers from female lineages showed very little sensitivity towards halothane induction and that the occurrence of PSE meat in this lineage is related to environmental factors.

\section{ACKNOWLEDGMENTS}

This work was partially funded by Fundação Araucária/FINEP, Fundação Araucária/CNPq Pronex (Protocol \# 09.277). Thanks also to the CAPES Foundation for a graduate scholarship to DFM and ILZ. EII and MS are CNPq Research Fellows.

\section{RESUMO}

O objetivo deste trabalho foi avaliar a sensibilidade de aves de uma linhagem fêmea ao halotano e sua relação com o desenvolvimento de carnes PSE. O teste do halotano foi conduzido com o auxílio de uma câmara anestésica com 3,0\% de halotano volatilizado. As aves inconscientes foram examinadas pelo enrijecimento dos seus membros inferiores. Quando ambos ou um dos membros permaneceram rígidos, os frangos foram classificados como sensíveis ao halotano (HAL+) e os frangos sem enrijecimento dos membros foram classificados como não-sensíveis (HAL-). Os resultados mostraram que de 298 frangos com 42 dias de idade, 95,6\% foram HAL-, e apenas 4,4\% HAL+. O peito foi coletado das aves HAL$(n=105)$ e HAL+ $(n=13)$ em que o $\mathrm{pH}$ e Cor $\left(\mathrm{L}^{*}, \mathrm{a}^{*}, \mathrm{~b}^{*}\right)$ foram determinados a $4^{\circ} \mathrm{C}, 24 \mathrm{~h}$ 
postmortem. Interessantemente, apenas $2,5 \%$ das aves HAL+ demonstraram carnes PSE, enquanto que as aves HAL- apresentaram 12,7\% de carnes PSE, em relação ao total de aves abatidas. O teste do halotano demonstrou que frangos da linhagem fêmea mostraram pouquíssima sensibilidade ao halotano, indicando que a ocorrência de carnes PSE está mais associada a fatores ambientais.

\section{REFERENCES}

Bendall, J. R. and Wismer-Pedersen, J. (1962), Some properties of the fibrillar proteins of normal and watery pork muscle. Journal of Food Science, 24, 144-457.

Candek-Potokar, M.; Zlender, B.; Fefaucher, L. and Bonneau, M. (1998), Effects of age and/or weight at slaughter on longissimus dorsi muscle: biochemical traits and sensory quality in pigs. Meat science, 48, 287-300.

Cavitt, L.C., Hargis, B.M. and Owens, C.M. (2004), The use of halothane and succinylcholine to identify broilers prone to developing pale, soft, exudative meat. Poultry Science, 83, 1440-1444.

Dransfield, E. and Sosnicki, A. A. (1999), Relationship between muscle growth and poultry meat quality. Poultry Science, 78, 743-746.

Fujii, J.; Otsu, K.; Zorzato, F.; Leon, S.; Khanna, V. K.; Weiler, J. E; O`Brien, P. J. and MacLennan, D. H. (1991), Identification of Mutation in Porcine Ryanodine Receptor Associated with Malignant Hyperthermia. Science, 253, 448-451.

Guarnieri, P. D.; Soares, A. L.; Olivo, R.; Schneider, J.; Macedo, R. M. G.; Ida, E. I. and Shimokomaki, M. (2004), Presslaughter handling with water shower spray inhibits PSE (Pale, Soft, Exudative) broiler breast meat in a commercial plant. Biochemical and ultrastructural observations. Journal of Food Biochemistry, 24, 269-277.

Marchi, D. F.; Oba, A.; Soares, A. L.; Ida, E. I.; Shimokomaki, M. (2008), Genetic origin of broiler PSE meat. Paper presented at $23^{\text {th }}$ Word's Poultry Congress, Brisbane, Australia.

Marchi, D. F.; Oba, A.; Ziober, I. L.; Soares, A. L. ; Ida, E. I. ; Shimokomaki, M. (2009). Development of a gas chamber for detecting broiler chicken halothane sensitivity and Pale, Soft and Exudative (PSE) meat formation. Brazilian Archives of Biology and Technology. In press.
Mickelson, J. R. and Louis, C.F. (1996), Malignant hyperthermia: excitation-contraction coupling, $\mathrm{Ca}^{2+}$ release channel, and cell $\mathrm{Ca}^{2+}$ regulation defects. Physiology Review, Baltimore, 76, 537-592.

Mitchell, G. and Heffron, J. J. A. (1982), Porcine stress syndromes. Advances in Food Research, 28, 167230.

Oba, A.; Soares, A. L.; Ida, E. I. and Shimokomaki, M. (2006), A evolução da seleção genética do frango e as anomalias que afetam a produção das carnes. Aveworld, 48-51.

Olivo, R., Soares, A. L., Ida, E. I. and Shimokomaki, M. (2001), Dietary Vitamin E inhibits poultry PSE and improves meat function properties. Journal of Food Biochemistry, 25, 271-283.

Owens C. M.; Mathews, N. S. and Sams, A.R. (2000), The use of halothane gas to identify turkeys prone to pale, exudative meat when transported before slaughter. Poultry Science, 79, 789-795.

Santini, G. A. (2006), Dinâmica tecnológica da cadeia de frango de corte no Brasil. Análise dos segmentos de insumo e processamento. Thesis, São Carlos Federal University, São Carlos, Brazil.

Scheuermann, G. N. (2008), Alteração na quantidade e qualidade da carne de aves através da manipulação das fibras musculares. Disponível em http://www.avisite.com.br/ Acesso em 23 de abril de 2008.

Simões, G. S. Oba, A., Matsuo, T., Rossa, A., Shimokomaki, M., Ida, E. I. (2009b). Vehicle thermal microclimate evaluation during Brazilian summer broiler transport and the occurrence of PSE (Pale, Soft, Exudative) meat. Brazilian Archives of Biology and Technology. In press.

Soares, A. L.; Lara, J. A. F.; Ida, E. I.; Guarnieri, P. D.; Olivo, R. and Shimokomaki, M. (2002), Variation in the color of brazilian broiler breast fillet. Proceedings of International Congress of Meat Science and Technology, 48, 540-541.

Soares, A. L.; Santos, T. N.; Marchi. D. F. Oba, A.; Ida, E. I. and Shimokomaki, M. (2007), Similaridades entre os sintomas da Síndrome do Estresse das Aves (PtSS) e da Síndrome do Estresse Suíno (PSS), originando as carnes PSE de frangos. Revista Nacional da Carne, 69-74.

Wheeler, B R. McKee, S. R.; Matthews, N. S.; Miller, R.K. and Sams, A.R. (1999), A halothane test to detect turkeys prone to developing pale, soft, and exudative meat. Poultry Science, 78, 1634-1638. 


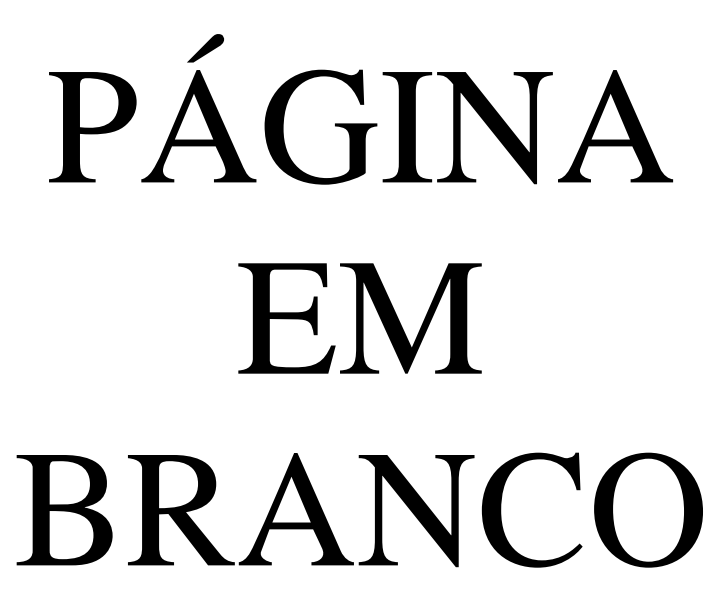

